\title{
Corynebacterium kroppenstedtii
}

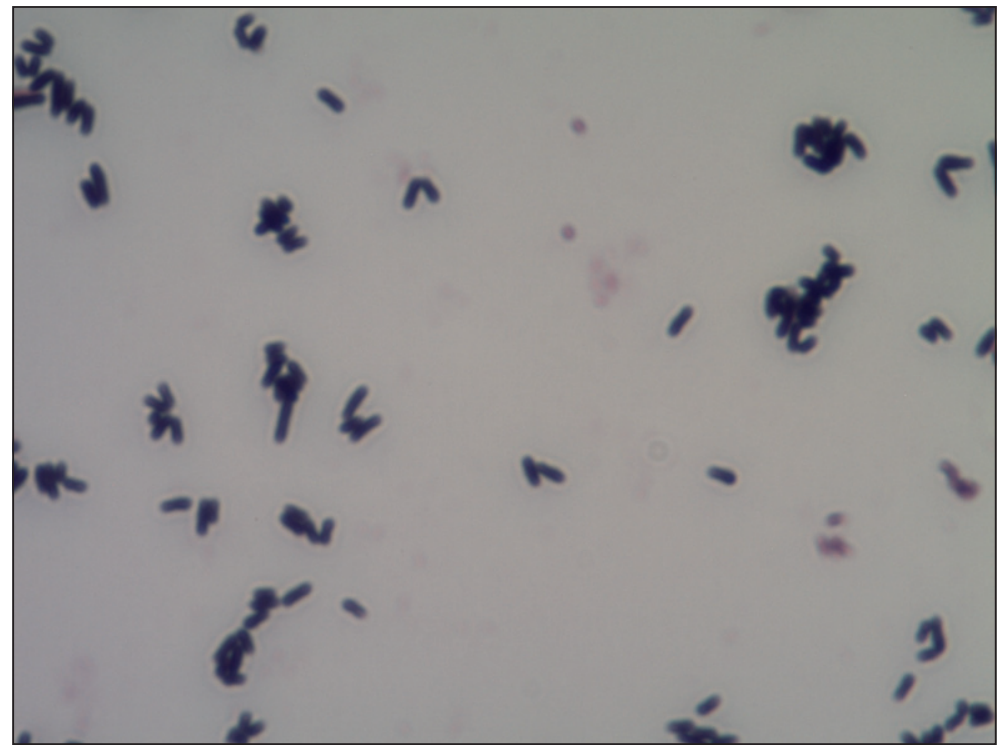

Figura 1. Tinción de gram de colonia de Corynebacterium kroppenstedtii en agar sangre de cordero $5 \%$.

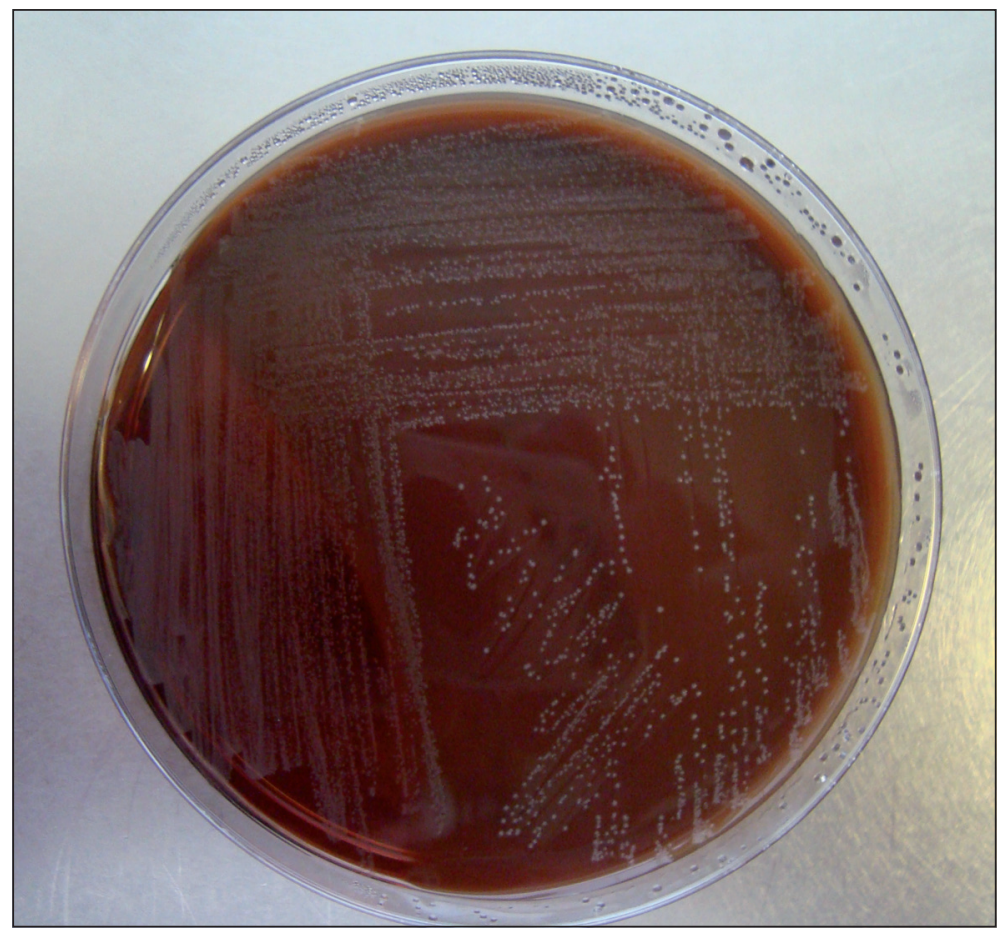

Figura 2. Cultivo de Corynebacterium kroppenstedtii en agar sangre de cordero 5\% (Foto Sr. Matías Vergara Villavicencio, alumno tecnología médica Universidad Andrés Bello). 


\section{Corynebacterium kroppenstedtii}

$\mathrm{D}$ ebido a que el género Corynebacterium forma parte de la microbiota humana cutánea, es difícil distinguir si el hallazgo de una de sus especies en una muestra clínica traduce infección, colonización o contaminación. Sin embargo, cuando se los encuentra en aislados repetidos, asociados a polimorfonucleares o como microorganismos únicos en muestras de tejido o aspirado y en presencia de un cuadro clínico compatible, su rol como agentes infecciosos adquiere relevancia. Este es el caso de Corynebacterium kroppenstedtii, un bacilo grampositivo "corineforme" poco frecuente, que fue descrito por primera vez en 1998 por Collins et al. a partir del esputo de una paciente con patología pulmonar. Posteriormente, se le ha recuperado de biopsias de pulmón, esputo, abscesos mamarios y de pacientes con mastitis granulomatosa globular.

Las colonias son grisáceas, traslúcidas y puntiformes $(<0,5 \mathrm{~mm})$ a las 24 horas de incubación a $37^{\circ} \mathrm{C}$ en agar sangre de cordero con $5 \% \mathrm{CO}_{2}$. La tinción de Gram muestra bacilos grampositivos irregulares, en empalizada y no ramificados. Produce ácido a partir de glucosa y sucrosa, es pirazinamidasa positivo y no posee ácidos micólicos. Es catalasa negativa e inmóvil. Sus características distintivas son la hidrolisis de la esculina y la lipofilia. Esta última es su factor de virulencia más importante. La literatura científica indica que los códigos de sistema API Coryne (BioMérieux, Francia) para Corynebacterium kroppenstedtii incluyen 0101104, 2040104, y 2040105. La tarjeta Vitek 2 ANC (anaerobios y Corynebacterium) no incluye esta especie en su taxa. La identificación definitiva es difícil por métodos rutinarios y habitualmente se requiere de biología molecular (RPC 16S ARNr) o espectrometría de masas (MALDI-TOF MS).

El estudio de susceptibilidad puede realizarse en caldo Mueller Hinton con ajuste de cationes y sangre de caballo lisada (2,5\% a 5\% v/v) de acuerdo a las recomendaciones del documento CLSI M45-A2. Penicilina y vancomicina se encuentran entre los fármacos primarios a estudiar. Doxiciclina y pristinamicina se han utilizado con éxito terapéutico.

\section{Referencias}

1.- Funke G, Bernard K. Coryneform gram-positive rods. Versalovic J, Carroll K, Funke G, Jorgensen J, Landry M, Warnock D, Manual of Clinical Microbiology, 10th ed. Washington, D.C., ASM Press; 2011, p. 413-42.

2.- Le Flèche-Matéos A, Berthet N, Lomprez F, Arnoux Y, Le Guern A-S, Leclercq I, et al. Recurrent breast abscesses due to Corynebacterium kroppenstedtii, a human pathogen uncommon in Caucasian women. Case Reports in Infectious Diseases 2012; Article ID 120968. doi:10.1155/2012/120968.

Lorena Porte y Thomas Weitzel Unidad de Microbiología, Laboratorio Clínico, Hospital Militar de Santiago Laboratorio Clínico, Clínica Alemana Santiago, Universidad del Desarrollo 